\title{
COALBED METHANE: PLACES OF ORIGIN, PERSPECTIVES OF EXTRACTION, ALTERNATIVE METHODS OF TRANSPORTATION WITH THE USE OF GAS HYDRATE AND NANOTECHNOLOGIES
}

\author{
K. Hanushevych ${ }^{1 *}$, V. Srivastava ${ }^{1}$ \\ ${ }^{1}$ Department of Chemical and Biological Engineering, Colorado School of Mines, Golden, United States \\ *Corresponding author: e-mail kosganush@gmail.com, tel. +17203694403
}

\section{ВУГІЛЬНИЙ МЕТАН: МІСЦЯ ПОХОДЖЕННЯ, ПЕРСПЕКТИВИ ВИЛУЧЕННЯ, АЛЬТЕРНАТИВНІ МЕТОДИ ТРАНСПОРТУВАННЯ ІЗ ВИКОРИСТАННЯМ ГАЗОГІДРАТНИХ І НАНОТЕХНОЛОГІЙ}

\author{
К. Ганушевич ${ }^{1 *}$, В. Срівастава ${ }^{1}$ \\ ${ }^{1}$ Кафедра хімічного і біологічного інжинірингу, Колорадська гірнича школа, Голден, Сполучені Штати \\ *Biдповідальний автор: e-mail kosganush@gmail.com, тел. +17203694403
}

\begin{abstract}
Purpose. To investigate the main basic physical and chemical properties of coalbed methane (CBM), conditions of its formation and places of occurrence. Special attention is paid to CBM utilization using alternative methods such as gas hydrate technologies and nanotechnologies.

Methods. Analysis of geological conditions of CBM occurrence and its content in several countries and methods of increasing gas hydrate formation rate to intensify gas utilization.

Findings. The reserves of CBM in different countries are classified according to the amount of gas in each country. A wide review is given to the methods of gas hydrates formation rate intensification and nanotechnologies application using different chemical compounds to utilize and transport CBM by ground transportation.
\end{abstract}

Originality. Gas hydrates and dry water have been proposed as alternative methods of CBM utilization and transportation in a solid form.

Practical implications. Colossal amounts of methane released into the atmosphere from underground coal mines can be captured and converted into a solid or powder form for transportation over large distances under moderate thermobaric conditions.

Keywords: coalbed methane, greenhouse gases, gas hydrates, dry water, nanoparticles, gas transportation, use of surfactants, water spraying

\section{INTRODUCTION}

Coalbed methane is a natural gas adsorbed in coal, i.e. gas adsorbs on the surface of coal and is stored in micropores or is located in natural fractures of coal.

Its calorific value changes in a wide range depending on age and rank of coal, bedding depth and wetness (Rice, 1993). The amount of gas in coal bed primarily depends on temperature, pressure, fracturing degree, coal permeability and adjacent strata (Krevelen, 1961; Airey, 1968).

\subsection{Coalbed methane as a greenhouse gas}

Coalbed methane, having the same properties as ordinary natural gas, is a powerful greenhouse gas that is 21 times more potent than $\mathrm{CO}_{2}$ in terms of heat capture. But Dr. Drew Shindell and his colleagues from NASA have found that methane heat-trapping potential can be not only $21-25$ times greater but it can be more potent by 105 times compared to $\mathrm{CO}_{2}$ when methane interacts with some aerosols in the atmosphere within a 20-year period of time and 79 times without aerosol effects (Shindell et al., 2009).

As an explosive gas (it is most explosive in the range of concentration from 5 to $15 \%$ ), it presents the risk of sudden outbursts during underground coal extraction, which is considered to be one of the most important factors influencing the volume of extracted coal within a specific period of time and, hence, leads to worsening of economical performance of a given mining enterprise.

As the coal is broken, it releases free methane into the mine openings and, as a result, the concentration of 
$\mathrm{CH}_{4}$ gradually rises to a dangerous level unless safety measures are taken in time. There are also official regulations as to the concentration of methane and other toxic and harmful for human's health gases at the working face, in return air or incoming air splits and also for local accumulations (Tien, 1996). If safety measures are not taken in time or in advance, methane released from coal mixes with oxygen and becomes explosive causing disasters underground.

The implemented safety measures are usually the injection of fresh air into the coal face, sucking out methane from the face to the surface or combination of these two methods using local ventilation fans.

Except for the safety reasons, the "gas factor" significantly slows down all kinds of mining operations taking place underground, and sometimes the operations must be fully stopped with possible evacuation of workers from the working area until the concentration of $\mathrm{CH}_{4}$ in the mine's atmosphere will come back to the norm. Only then can the operations be continued.

Nowadays the mining depth is continuously increasing as coal reserves located closer to the surface are being depleted. And there is a common correlation between mining depth and gas content - the deeper you go the more gas you have (Guidebook..., 1999). So, as the gas content in coal is also increasing, it leads to the rise of the number of possible gas explosions, drawbacks in production and, hence, to worsening of the mining enterprise economical situation.

Nowadays, one of the most effective and safest ways to reduce the amount of gas underground is preliminary degasification (gas drainage) using degassing wells drilled into the coal seams before mining operations even start (A Regional Handbook..., 2011). This method successfully solves the safety concerns as there is almost no methane left underground when mining begins. Also, this method can be used during mining operations.

Preliminary degasification solves the following issues:

1. Safety aspect: increases safety of mining due to mitigation of gas factor and this leads to higher production volumes of the enterprise.

2. Ecological aspect: $\mathrm{CH}_{4}$ is a powerful greenhouse gas that is $21-23$ times more powerful than $\mathrm{CO}_{2}$. Even if to flare methane, it releases $\mathrm{CO}_{2}$. So, this way of $\mathrm{CH}_{4}$ utilization does not fully solve the issue of the environment pollution.

3. Energy aspect: additional source of energy for the population: heating buildings, generating electrical power, fuel for vehicles as well as for the industrial needs.

Also, the recovery can also be implemented during or after mining operations (from worked-out areas) using both vertical and directional drilling depending on geological conditions and properties of the coal seam. The selection of drilling technique strictly depends on bedding depth and geology of the coal reservoir. Usually, the deeper the coal seam, the more complex technique has to be implemented (Bue, 2012).

The principle scheme of coalbed methane extraction technology is shown in Figure 1. The borehole should cover the area with the biggest number of fractures. Sometime a grid of boreholes is used to cover a larger area.
Coalbed Methane Well

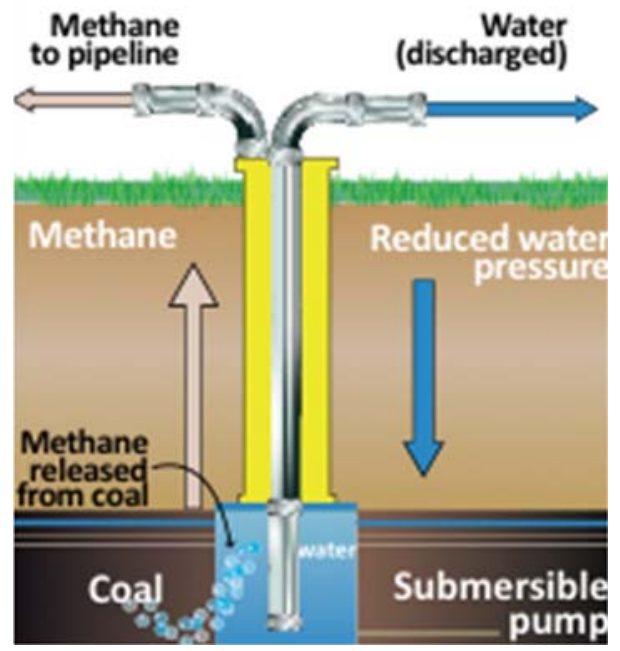

Figure 1. CBM recovery basic scheme (Fossil Energy..., 2012)

The basic principle behind CBM extraction is introducing water into the coal seam through a borehole to make the gas flow up when water is removed lowering the pressure in the bed. The pumps located at the bottom of the borehole are used to pump an excessive amount of water and sucking out the gas from the coal seam (Stearns, Tindall, Cronin, Friedel, \& Bergquist, 2005). But this method is mostly good for coals with high level of permeability. If the permeability is not high enough, hydraulic fracturing technique, just like in shale gas extraction, can be used to connect the well with the system of cleats and, hence, to increase the gas flow (Davidson, Sloss, \& Clarke, 1995). Another, even more efficient, technique implies introduction of water and air under a very high pressure and after that, rapid drop in pressure causes explosion of rock, thus increasing the diameter of the production well and area of the fractures (Coalbed Methane..., 2012). There is also a method of injecting chemicals such as hydrochloric acid into the coal seam to enlarge the size of cleats in coal (Kumar \& Mathews, 2006).

The safety concerns are paid the biggest attention to in underground mines all over the planet, although, for fairness' sake, it should be mentioned that in Ukraine, according to one of the present article authors, who has some experience in working underground, miners daily violate various safety regulations so that there are no operational downtimes or delay in production that would cut the miners' salary. Also long-term underinvestment has led to unsafe, outdated equipment that presents its own danger of failure and causing a disaster (Ukraine's Mine..., 2007).

Very similar situation is also observed in Russian coal mines. May 2010 saw a huge methane-blast disaster in Russia's biggest underground coal mine "Raspadskaya" killing 66 people and injuring 99, with other 24 considered missing. As it was explained by consequent investigations, this happened because of outdated equipment, failure to follow safety regulations and absence of degasification systems installed at mines (Raspadskaya mine..., 2010). In 2007,150 coal miners were killed by two consecutive explosions of methane underground. 
According to RosTechNadzor, the explosions were caused by failure to check concentration of methane in the mine atmosphere and violations of ventilation requirements (Coal Mine Methane in Russia, 2009).

\section{GLOBAL RESERVES OF COALBED METHANE}

One of the fundamental laws in mineral resources exploitation is the Law of natural resources limitation that originates from the fact that the planet of Earth is one solid piece, hence, it cannot have limitless pieces (parts) existing on it. So, the category of "inexhaustible" minerals simply is not applicable to our planet. Therefore, if we cannot escape depletion of natural resources, it is necessary to pay specific attention to a more complete (comprehensive) use of them. That means utilizing any byproducts or implementing their continuous recycling to make the technology ecologically friendly and maximum profitable.

According to the BP Statistical Review of World Energy (Statistical Review..., 2008), the largest proven coal reserves belong to the USA with $28.6 \%$ of the total amount of coal on the planet. Russia takes the second place, having $18.5 \%$, then China with $13.5 \%$, Australia with $9.0 \%$ and India $(6.7 \%)$.

But, at the same time, according to US DOE (AlJubori et al., 2009), Russia takes the first place in the world in terms of coalbed methane reserves (Table 1).

Table 1. Largest reserves of coalbed methane by countries

\begin{tabular}{lc}
\hline \multicolumn{1}{c}{ Country } & Quantity, Tcf \\
\hline Russia & 1.730 \\
USA & 1.037 \\
China & 1.307 \\
Australia & 1.037 \\
Canada & 699.000 \\
United Kingdom & 102.000 \\
India & 71.000 \\
Ukraine & 42.000 \\
Kazakhstan & 23.000 \\
\hline
\end{tabular}

It should be mentioned that Alaska alone has immense reserves of CBM equal to about 1.037 Tcf (Al-Jubori et al., 2009). As seen from Table 1, there are 4 other countries except the previously listed coal giants, present on the coalbed methane market with fairly large reserves: Canada, United Kingdom, Ukraine and Kazakhstan. Studies conducted by the Environmental Protection Agency of the United States of America show that $33 \%$ of all global emissions of coal mine methane belong to China, 13\% to the USA, $6 \%$ - to Russia and the same amount to Ukraine (Coal Mine Methane in Russia, 2009).

According to another source (Thakur, 2017), coalbed methane reserves are distributed somehow differently on our planet (Table 2). In this Table, the USA takes only the fifth place by global reserves of coalbed methane, followed by Ukraine that is behind India. Canada, according to these studies, takes the first place compared only with the fifth given by Schlumburger in 2009 (AlJubori et al., 2009). Germany and Poland that are not even presented in Table 1, rank number 8, having 3 trillion $\mathrm{m}^{3}$ of coalbed methane each. Also the Republic of South Africa and Turkey appear among the biggest countries it terms of coalbed methane reserves according to studies conducted in 2003.
Table 2. Coalbed methane reserves by countries

\begin{tabular}{lc}
\hline \multicolumn{1}{c}{ Country } & $\begin{array}{c}\text { Reserves evaluation, } \\
\text { trln } \mathrm{m}^{3}\end{array}$ \\
\hline Canada & $17-92$ \\
Russia & $17-80$ \\
China & $30-35$ \\
Australia & $8-14$ \\
USA & $4-11$ \\
Ukraine & $2-12$ \\
India & $0.85-4$ \\
Germany & 3 \\
Poland & 3 \\
Great Britain & 2.45 \\
Kazakhstan & $1.1-1.7$ \\
RSA & 1 \\
Czech Republic & 0.38 \\
Turkey & 0.1 \\
\hline
\end{tabular}

So, it turns out that there is a significant difference in data provided between 2003 and 2009, and some countries, such as Germany, Poland, RSA, Czech Republic and Turkey, they are not even present in 2009's studies but listed in the 2003's review. According to CBM, Asia Development Corporation, Indonesian reserves of CBM are estimated to be $453 \mathrm{Tcf}$, which has never been stated by other sources.

Are there some miscalculations possibly incurred or is it an intentionally biased approach?

\subsection{Britain's coalbed methane}

According to the Department of Energy and Climate Change (DECC) (The Unconventional Hydrocarbon..., 2013), even if $10 \%$ of the UK CBM is recovered, it would correspond to UK's three-year natural gas supply. The UK's National Coal Board that conducted a program of measuring gas content in their coals back in the 1980 's, has found that typically the coalbed methane had $80-95 \%$ of methane, $0-8 \%$ - ethane, $0-4 \%$ - propane and higher alkanes, $2-8 \%$ - nitrogen, $0.2-6 \%$ - carbon dioxide (Creedy, 1991).

\subsection{India's coalbed methane}

Due to high prices for LNG (liquefied natural gas) and rapidly growing demand for energy sources, Indian government has started putting an accent on coalbed methane extraction. There are eight potentially attractive CBM fields in India at the moment: Jharkhand, West Bengal, Madhya Pradesh, Rajasthan, Chhattisgarj, Andhra Pradesh, Maharashtra and Gujarat (Developments in India-CMM/CBM, 2010). The gas content in these coal fields is evaluated to be within $7.3-23.8 \mathrm{~m}^{3}$ per ton of coal at the depths of $150-1200 \mathrm{~m}^{3}$. For these coals, an increase of each 100 meters down leads to the increase of methane content of about $1.3 \mathrm{~m}^{3}$ per ton (Ojha, Karmakar, Mandal, \& Pathak, 2011).

According to miningweekly.com from October $28^{\text {th }}$, 2015 (India's ONGC..., 2015), India's ONGC (Oil and Natural Gas Corporation Limited) is investing 400 million dollars into development of two CBM coal blocks to start the production. ONGC is planning to drill about 80 wells over the next three years, starting in 2016 . There are four largest CBM blocks that can be distinguished: Jharia - with 85 billion $\mathrm{m}^{3}$, North Karanpura - 
62 billion $\mathrm{m}^{3}$, Bokaro -45 billion $\mathrm{m}^{3}$ and Raniganj North -43 billion $\mathrm{m}^{3}$ (ONGC to invest..., 2015).

From the words of Prashant Modi, Chief Operating Officer of Great Eastern Energy Corporation (GEECL), India has a great potential and is a very attractive country for CBM producers, considering the fact that this country has the fifth-largest reserves of coal in the world. There is no cost for recovery and only 10 per cent royalty to the government plus a biddable percentage on sales (Real Potential..., 2015). Also, after the gas is recovered, the producer has the right to sell it on the domestic market at any price. So, the CBM contract appears to be very attractive both for domestic and foreign investors. GEECL has already drilled about 156 wells reaching productivity of about $22.8 \mathrm{mcf}$ per day.

\subsection{USA's coalbed methane}

Methane is usually the main component of coalbed gas, although it also has a variety of other hydrocarbons in its composition, such as propane, butane, hydrogen sulfite, carbon dioxide. According to Pittsburgh Mining and Safety Research Center, methane concentration in coalbed methane of various coal deposits all over the USA varied from 63 to $99 \%$, carbon dioxide - from 0.1 to $15 \%$, although no correlation depending on age, rank or bedding depth has been found for these two gases (Kim, 1973).

The studies conducted by Ann G. Kim represent tests for gas composition of several coalbed samples taken from multiple coal fields at different coal mines. Tests for gas composition have shown that it is methane that is of the highest concentration in each gas sample. Its highest value was $99.22 \%$ and lowest $63.1 \%$. Ethane was usually present in all gas samples, propane and butane were not as common. Carbon dioxide and sometimes nitrogen and hydrogen were present in very small quantities. The heat of combustion for most of the tested samples was quite comparable to the values of natural gas.

\subsection{Russia's coalbed methane}

Coal in Russia is notable for its high methane content. And there is only about $20 \%$ of mine methane released into the atmosphere that is captured. All the remaining billions of cubic meters of methane go straight into the atmosphere. According to Gazprom (O perspektivakh dobychi..., 2017), reserves of coalbed methane in Russia present about one third of the country's reserves of natural gas. Since 2003 the OJSC "Gazprom Dobycha Kuznetsk" - the only coalbed methane recovering company in Russia has started extraction. Currently, the company has been developing three huge deposits (Puchcov, Slastunov, \& Karkashadze, 2006).

The average methane content of coal by countries (Ruban, 2006) is presented the Table 3.

Table 3. Average methane content of coal by countries

\begin{tabular}{lc}
\hline \multicolumn{1}{c}{ Country } & $\begin{array}{c}\text { Average methane } \\
\text { content, } \mathrm{m}^{3} / \mathrm{t}\end{array}$ \\
\hline Russia & 11.6 \\
UK & 10.3 \\
China & 9.3 \\
USA & 7.0 \\
Germany & 5.0 \\
\hline
\end{tabular}

In 2008, coal methane emissions in the Kuznetskiy basin (one of the biggest basins) increased to $320 \mathrm{mln} \mathrm{m}^{3}$ a year, compared to $252 \mathrm{mln} \mathrm{m}^{3}$ in 2006 , but the volume of utilized methane stayed very low - about $40 \mathrm{mln} \mathrm{m}^{3}$ for local use in boilers (Coal Mine Methane in Russia, 2009).

Degasification of coal in Russia is only considered to be viable for gas content of more than $10 \mathrm{~m}^{3}$ per ton of coal. So, the coalbed methane recovery coefficient stays very low - 0.2 (Puchcov, Slastunov, \& Karkashadze, 2006). The other thing is that reserves of natural gas in Russia are truly immense, and it tops the list of ten biggest countries in terms of natural gas reserves, thus, development of coalbed methane recovery technologies cannot compete with conventional methods in terms of strategic importance at this stage of the energy sector development.

\subsection{China's coalbed methane}

According to data provided by (Che et al., 2008) the resources of CBM in China are estimated at $36.8 \cdot 10^{12} \mathrm{~m}^{3}$. At this moment, there are 15 national projects and 6 demonstration projects under way (Wu, Sun, \& Feng, 2011). At the same time, safety level in underground mines of China is improving.

According to (Mu et al., 2015), the major problems concerning CBM recovery at this moment are poor understanding of geological conditions, low production of wells and lack of investments. There is also a problem related to lack of pipelines for gas transportation leading to venting of "excess" gas into the atmosphere.

Meanwhile, the Chinese government has started paying a lot of attention to the environment protection and air pollution prevention and such an initiative directly involves utilization of coalbed methane reserves. There are six major CBM production fields in China at the moment with predicted productivity of about $600 \cdot 10^{8}-820 \cdot 10^{8} \mathrm{~m}^{3} /$ year. So, the overall picture of CBM recovery perspectives in China is very promising.

\subsection{Australia's coalbed methane}

In Australia, coalbed methane is usually referred to as coal seam gas (CSM) and coal seam methane (CSM) depending on the location in the country. But the part of methane that is vented into the atmosphere through ventilation systems is called ventilation air methane (VAM) (Coalbed Methane, 2006). VAM is considered to be the largest source of methane in Australia in terms of amount of emissions into the atmosphere (Miyazaki, 2005).

There are two major coal basins in Australia - Bowen and Surat that have suitable conditions, in terms of bedding depth, for CSM extraction. The mean volume of methane per 1 ton of coal is rather high $-25 \mathrm{~m}^{3}$. Australia's total reserves of coalbed methane are estimated to be from 8.6 to 14.3 trillion $\mathrm{m}^{3}$. To enhance productivity, nitrogen $\left(\mathrm{N}_{2}\right)$ and carbon dioxide $\left(\mathrm{CO}_{2}\right)$ can be injected into the coal seam to increase coal permeability: nitrogen reduces pressure of methane and, hence, its flow, and carbon dioxide removes methane from the coal surface and adsorbs on the coal surface (Ham \& Kantzas, 2008).

According to the forecast made by CBM Asia Development Corporation, Australia has all the chances to become \#1 CBM producer in the world displacing the USA by 2020 . 


\subsection{Germany's coalbed methane}

Based on studies made by Mosle et al (Mosle, Kukla, Stollhofe, \& Preube, 2009), Germany has CBM reserves of about 3 trillion $\mathrm{m}^{3}$. There are three main coal fields in Germany: Ruhr, Ibbenburen and Saar (Brown Coal Statistics, 2014).

As of 2014, there are $43 \mathrm{CBM}$ projects operating in Germany. 37 of these projects are abandoned mines. 30 projects serve for power generation, the rest 13 - for combination of heat and power (Global Methane Initiative, 2014). According to the same source, the amount of abandoned mine methane (AMM) captured annually in Germany is equal to more than 400 million $\mathrm{m}^{3}$. The potential utilization of CBM in Germany can be associated with boilers, heat and power generation, secondary fuel sources such as methanol, liquid gas, chemical industry, coking plant, electrical power plant (Dinkelbach \& Mader, 2004).

\subsection{Ukraine's coalbed methane}

Ukraine is one of the biggest coal and coalbed methane producing countries in the world. It is the fourth largest coal producer in Europe after Russia, Germany and Poland. Its 33.9 billion tons of coal is enough to sustain current consumption rates for the next 390 years. Most of Ukrainian underground coal mines (about 80\%) are highly gassy (more than $15 \mathrm{~m}^{3}$ of gas per 1 ton of coal) and prone to sudden outbursts of gas and coal dust with thickness of coal seams only within the range of $0.4-1.5 \mathrm{~m}$ (Coal of Ukraine, 2013). For this reason, extraction of coal in Ukraine is both technologically and ecologically difficult task requiring modern equipment and wise approach.

Specific methane content in Ukrainian coal is about $20 \mathrm{~m}^{3}$ per ton (Coal Mine Methane in Ukraine, 2001) that is a quite high value.

Nevertheless, almost all of its CBM is just vented into the atmosphere. 10 percent of utilized methane is degasified with the help of drilling three types of wells from the surface: vertical, horizontal and wells drilled through the coal seam and surrounding rocks. Vertical wells are used as means of preliminary degasification removing about $70 \%$ of methane, i.e. before even mining operations start. The utilized gas is primarily used in mine boilers instead of using coal.

Horizontal boreholes are used to suck methane out of unmined areas. They are usually from 30 to 50 meters long. However, the efficiency of this method can be 50\% less than when using vertical boreholes. All wells are connected to a central vacuum pump by a system of interconnected pipelines (Ukraine Coalbed Methane ..., 1998).

Nowadays Ukraine is heavily dependent on imported natural gas, therefore, any source of gas within the country would benefit its economy and would be a crucial step towards even partial sustainable energy existence.

Extracted mine gas can, at least, partially replace the gas imported from Europe and Russia, improve ecological and economic situation in the country.

\section{UTILIZATION OF COALBED METHANE}

Taking into account the fact that CBM in not only a dangerous gas threatening miners but also a colossal source of natural gas, it is proposed to use an alternative method of gas transportation without pipelines. One of these methods can be usage of gas hydrate technologies. Since gas hydrates are well known for consuming large amounts of gas under high pressures and low temperatures forming solid crystalline compounds (complexes), they can be used to transport gas in a solid gas hydrate form.

But the main challenge of implementing such an idea is intensification of gas hydrate formation process, its storage and transportation. The time of gas hydrates formation depends on many factors, such as various gases concentration in the gas mixture, water content, presence of dust particles in the gas, moisture content in the gas, rate of cooling, speed of diffusion, thermodynamic driving force (Kashchiev \& Firoozabadi, 2002; Anklam \& Firoozabadi, 2004; Mottahedin, Varaminian, \& Mafakheri, 2011; Fandiño \& Ruffine, 2014).

There are several ways to promote gas hydrate formation rate known at present: use of surfactants (Kumar, Bhattacharjee, Kulkarni, \& Kumar, 2015), water spraying to increase surface area between phases (Brown, Taylor, \& Bernardo, 2010), use of dry water concept (both of speeding the process and transportation) (Wang, Bray, Adams, \& Cooper, 2008), hollow silica (Prasad, Sowjanya, \& Dhanunjana Chari, 2014), use of copper nano-particles in water (Li, Liang, Guo, Wang, \& Fan, 2006), even use of potato starch (Fakharian, Ganji, Naderi Far, \& Kameli, 2012).

After the gas hydrate is created, it needs to be stored and transported. The following promising methods are proposed at present: creating gas hydrate pellets for convenient transportation (Katoh \& Fukazawa, 2011; Rehder et al., 2012), transportation in trucks (Mimachi et al., 2014; Taheri, Shabani, Nazari, \& Mehdizaheh, 2014;), shipping in vessels (Mannel \& Puckett, 2008), storage as frozen hydrates (Gudmundsson, Parlaktuna, \& Khokhar, 1994), transportation of hydrate slurry (Martin, Sinquin, \& Darbouret, 2011; Lv, Shi, Wang, \& Gong, 2013).

\subsection{How do surfactants work?}

Surfactants (also hydrate promoters) are mainly used to increase water-to-hydrate conversion and enhance watergas interactions. So, the induction time that occurs right after nucleation is reduced due to the use of promoters (surfactants), whereas, growth rate gets extended (Kumar, Bhattacharjee, Kulkarni, \& Kumar, 2015). The right amount of a surfactant can even change the morphology enhancing better water-gas contact and, therefore, increase growth rate of a hydrate (Kalogerakis, Jamaluddin, Dholabhai, \& Bishnoi, 1993; Zhong \& Rogers, 2000).

Surfactant coating reduces surface tension of water, since this monomolecular layer covering water surface has lower energy. In our case the system consists of a liquid phase, gas phase and surfactant. Thus, it is proposed that methane bubbles are injected through the water-surfactant solution. The number of bubbles reaches tens of thousands of billions in $1 \mathrm{~m}^{3}$.

The main condition is that gas bubbles have to be covered with the solution film not allowing them to get out of the system (Fig. 2). If such a film does not exist, the gas bubbles burst immediately (Artemenko, 1980). 


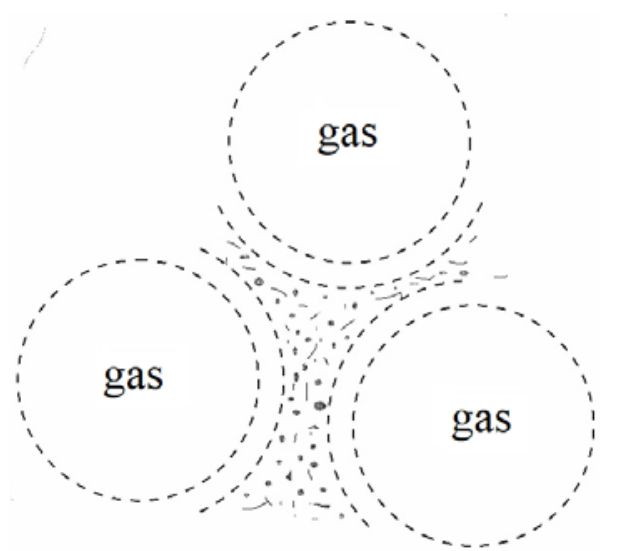

Figure 2. Gas bubbles covered with water-surfactant solution

Methane bubbles released onto the surface without using a surfactant, exist only some milliseconds, whereas, when using surfactant - they can exist for much longer periods of time. This is reached with the help of the water surface tension decrease. When surfactant is added, its molecules aggregate to form the so-called micelles (structures) in water with various forms and orientations (Fuhrhop \& Koning, 1996).

When water and a surfactant get in contact they form not only firm adsorption film at the solution-gas interphase and enhance gas bubbles stability, but also increase the possibility of formation of bubbles of critically important size.

According to the results obtained in the National Mining University (Ukraine), using a surfactant for promoting gas hydrate formation rate, it is of high importance to use an optimal amount of a surfactant. If there is not enough surfactant added to water, the structuring does not occur, because promoter molecules cover only some part of a water molecule surface and, therefore, do not structure it. On the contrary, when there is an excessive amount of a surfactant present in the system, the number of micelles will grow until they start to adhere to each other because there is not enough water between them serving as a lubricant (Ganushevych, Sai, \& Korotkova, 2014).

However, he above mentioned conclusions, most probably, do not refer to all the hydrate promoters. Promoter that has been used for methane hydrate growth rate is widely used in coal industry for coal dust suppression. Its chemical formula is presented on the Figure 3.

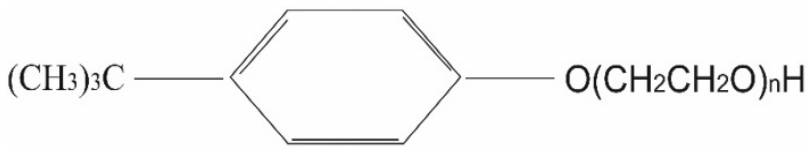

Figure 3. Structural formula of the used surfactant, where $n$ is equal to 7 (in average)

During the experiments, it was established that $\mathrm{O}\left(\mathrm{CH}_{2} \mathrm{CH}_{2}\right)_{n} \mathrm{H}$ group structures water into a hexagonal shape crystallizing it and, as a result, increasing the rate of hydrates formation (Fig. 4). Therefore, this surfactant promotes water carcass formation - "host" that encapsulates gas molecules forming gas hydrate.

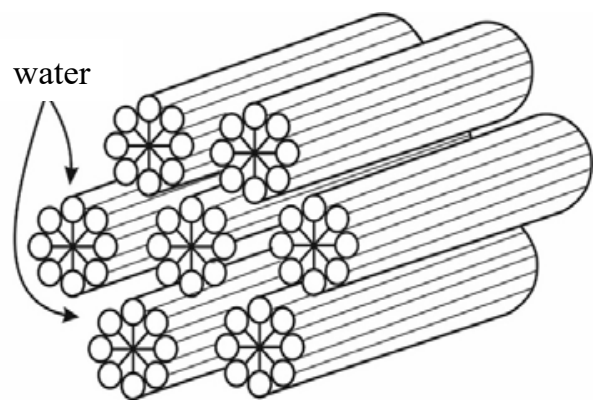

Figure 4. Water structuring by using the surfactant

\subsection{Water spraying}

The technology of water spraying in a form of a mist is also considered to be one of the methods for hydrate formation process intensification. The technique is realized with the help of high-pressure nozzles installed in a reactor. The number of nozzles can vary as well as the pressure under which the water is sprayed inside the cell. Water injection angle plays a role too, as it can significantly influence the phase interaction mechanism. The main idea of this technique is the creation of a bigger surface area of the phases contact which is critical for promoting faster nucleation of gas hydrate. Figure 5 schematically illustrates the basic of idea of this method.

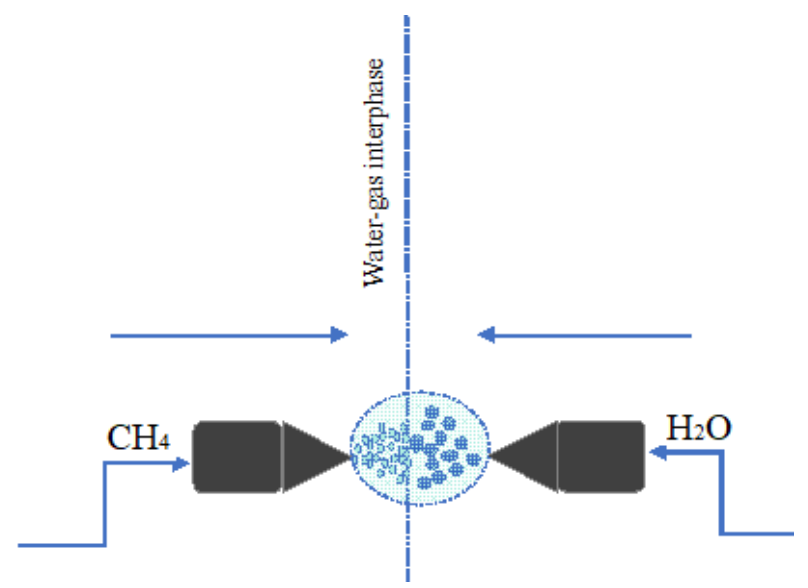

Figure 5. Schematic illustration of water-spray interaction with gas

The main operational parameters changing during the process are pressure and temperature inside the cell. These two parameters have a direct influence on guest molecule solubility in water which is proved by Song (Song et al., 1997). The results of his experiments state that a gas solubility in water significantly increases at temperatures right above gas hydrate formation temperature and right before hydrate formation. Similar conclusions have been made by Servio (Servio \& Englezos, 2002), confirming that methane solubility in water decreases after gas hydrate has been formed and increases right before its formation.

One of the critical factors in the water spraying technique is the size and, hence, weight of the water droplets released from the nozzle. It may appear that too small water droplets will not have enough kinetic energy and velocity to create an adequate water-gas phase boundary, not allowing gas molecules penetrate water droplets. 
Further into this question, Welander at al. has come up with a comparative table showing the connection of water droplet size, number of water droplets and total surface area: cutting droplet size in two yields 8 times more water droplets and doubles total surface area (Welander \& Vincent, 1999). This means nozzles selection is a crucial step for the effective realization of the method that needs deep analysis and examination to fully use the potential of the suggested method of promotion.

To help promote gas hydrate formation rate, it is proposed by Ryo Ohmura et al. (Ohmura, Kashiwazaki, Shiota, Tsuji, \& Mori, 2002) to use a second guest molecule, besides methane, that forms structure H-hydrate. It is explained by the fact that the pressure needed to create this type of hydrate - "methane + second guest molecule" is about $40 \%$ of what is required for the structure-1 hydrate.

To further promote the rate of gas hydrate formation, it is suggested to use mechanical stirring which facilitates and increases methane uptake by water (Brown, Taylor, \& Bernardo, 2010).

\subsection{Use of nanoparticles as promoters}

One of the most perspective methods influencing kinetics of gas hydrate formation at the moment is using nanoparticles of various chemical compounds such as $\mathrm{Al}_{2} \mathrm{O}_{3}, \mathrm{SiO}_{2}, \mathrm{Ag}$ and $\mathrm{Cu}$ (Said et al., 2016). According to the same authors, adding just an insignificant portion of a compound is able to change gas consumption volume and kinetics of gas hydrate formation.
As a result of their experiments, $\mathrm{SiO}_{2}$ has turned out to be the most effective chemical compound capable of increasing the average amount of consumed gas up to $45 \%$ compared with the value obtained when pure water was used for dissolution and $77 \%$ for crystallization. $\mathrm{Cu}$ and $\mathrm{Al}_{2} \mathrm{O}_{3}$ have proved to be not very effective in increasing consumption by only $1 \%$ using $\mathrm{Cu}$ and $15 \%$ using $\mathrm{Al}_{2} \mathrm{O}_{3}$ during dissociation but quite well during crystallization -30 and $65 \%$ correspondingly. The phenomenon of faster hydrate formation using different nanoparticles is explained by more efficient mass and heat transfer in fluids thanks to the particles.

\subsection{Dry water concept}

Based on the concept of nanoparticles usage to increase gas uptake and hydrate formation kinetics, $\mathrm{SiO}_{2}$ nanoparticles can be used not only to increase the kinetics of the process but also in developing an alternative transportation method of natural gas.

At the first stage, it is proposed to create the so called "dry water" - compound consisting of water droplets coated by hydrophobic fumed silica layer preventing droplets from blending (Wang, Bray, Adams, \& Cooper, 2008). Dry water (DW) looks like a white fine powder, which is dry on the surface but gets wet if the silica coating is broken and the water is let out. Figure 6 shows a supposed scheme of what DW might look like inside. The silica coating itself is measured on a nanoscale, whereas the water droplet is about $25-50$ microns in size (Shirato \& Satoh, 2011).

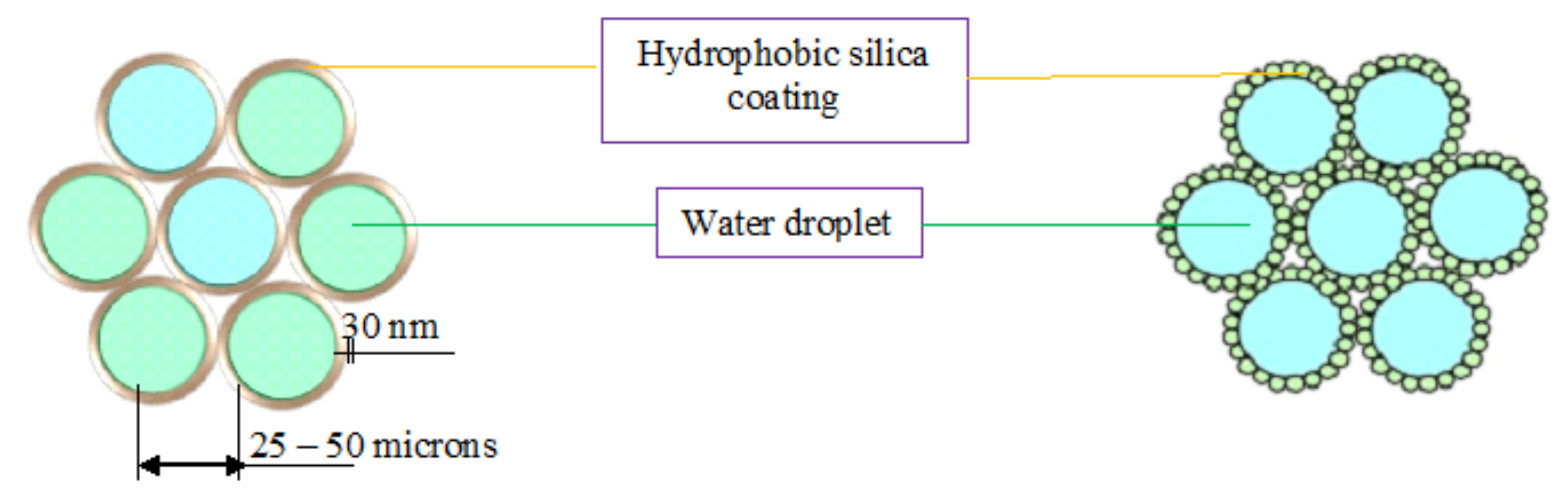

Figure 6. Two supposed schemes of what dry water looks like

To create DW, an ordinary blender is needed to mix up water with hydrophobic silica under free access of air (Fig. 7). The speed of stirring can vary in a wide range and strongly influences the size of created dry water particles. Average mixing time is only 90 seconds.

Depending on the water-hydrophobic silica ratio, there will be no phase separation (ideal case) or significant phase separation easily detected by a naked eye: foam or dispersion. It has been established that the perfect ratio of water and silica is 95 to $5 \%$ respectively. In this case a pure powder-like substance is formed (Fig. 8). As seen from the Figure 8, the perfect ratio (96 wt. \%) forms whitish powder-like substance with no visible phase separation at all.

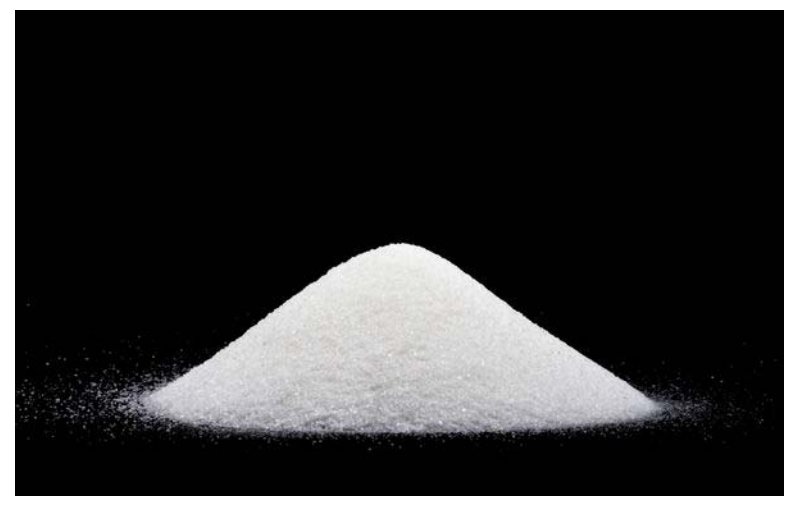

Figure 7. Sample of dry water (Bland, 2008) 


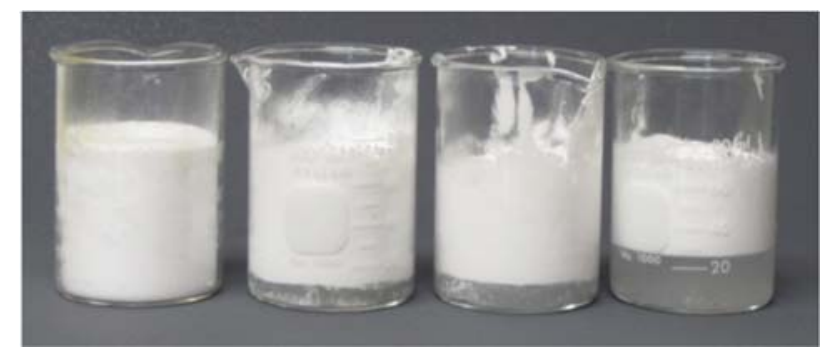

Figure 8. Phase separation depending on the water-silica content ratio. From left to right: 96, 97, 98, 99 wt.\% water (Altan \& Zhu, 2014)

Whereas the rightmost sample clearly demonstrates water and hydrophobic silica phases separation with the last one on top, it is worth noting that water content lower than $96 \mathrm{wt}$ \% may lead to clusters formation consisting of relatively large crystals.

The storage capacity of DW is what makes the compound really attractive. DW can uptake about 200 times more methane than the volume of DW itself under standard conditions (Hu et al., 2001).

Dry water concept seems to be extremely intriguing when it comes to the industrial application. The potential applications are as follows:

1. Storage of greenhouse gases such as $\mathrm{CH}_{4}$ and $\mathrm{CO}_{2}$ (due to molecules encapsulation).

2. Aqueous solutions containing hazardous chemical agents may also be encapsulated for safe handling, shipment and storage.

3. Safe and convenient transportation and storage in solid powder-like form.

4. High gas storage capacity (possibly higher than in bulk water hydrates).

There are still many questions arising as to practical usage of DW: transportation pressure-temperature conditions, more accurate influence of mixing on DW particles size, optimal water-silica ratio, silica coating thickness and its strength, cohesion forces between water droplet and silica, influence of water repeat usage on DW formation kinetics et cetera.

\subsection{Potato starch}

Finally, even potato starch can be used to increase the rate of gas hydrate formation compared to usage of just pure water (Fakharian, Ganji, Naderi Far, \& Kameli, 2012). According to the authors, the starch in concentrations from 100 to $500 \mathrm{ppm}$ enhances hydrate formation kinetics. In addition, acceleration effect directly depends on the increase of the starch concentration. Gas content of gas hydrates created with presence of starch can be compared with those created using SDS solution (sodium dodecyl sulfate) or even higher.

\section{CONCLUSION}

Coalbed methane is a natural gas located in pores and fractures of coal possessing a great risk of sudden outbursts leading to disasters in underground coal mines. However, CBM is a source of a tremendous amount of natural gas that can be used in power generation, auto fuel, steel manufacturing and for people's needs.
Common challenges when extracting CBM are shared by all gas producing countries: safety of the operations (especially if using hydraulic fracturing technique), protection of the environment, water utilization, governmental regulations, infrastructure and gas transportation methods.

One of the proposed methods to utilize CBM implies mixing it up with water under predefined thermobaric conditions and creating gas hydrates - solid compounds consisting of water and gas and existing under high pressure and low temperature. Creating gas hydrates is rather time consuming for an industrial implementation. Thus, gas hydrate formation rate needs to be accelerated.

At present, there are several sophisticated methods to increase gas hydrate formation kinetics. Using various surfactants is, probably, the most known method to enhance water-gas interaction and thus speed up the nucleation and growth of a gas hydrate decreasing its induction time. When choosing the amount of a surfactant to add, one should be careful, as miscalculations can lead to inhibiting gas hydrate nucleation rather than accelerating it.

Water spraying technique is also considered to be one of the most promising methods to enhance the kinetics of nucleation. With the help of tiny water droplets sprayed through the gas a bigger surface area forms that enlarges phase contact between water and gas. The main concern of this technique is that the size of water droplets should be not too small to interact with gas molecules.

Another method of promoting gas hydrate formation deals with nanoscale investigations. Such chemical compounds as $\mathrm{Al}_{2} \mathrm{O}_{3}, \mathrm{SiO}_{2}, \mathrm{Ag}$ and $\mathrm{Cu}$ are used to enhance gas hydrate formation rate thanks to their large surface area. It has been reported that not only does the formation rate increase but also gas consumption volume grows when using nanoparticles.

$\mathrm{SiO}_{2}$ has proved to be the most effective compound in terms of increasing kinetics and gas consumption compared to usage of pure water. The so called "dry water" created by blending $\mathrm{SiO}_{2}$ and water can be perfectly implemented as a means of a natural gas transportation in a powder form from the very place of gas release replacing old-fashioned pipeline method.

Based on the recent investigations, even potato starch in concentrations from 100 to $500 \mathrm{ppm}$ can be used as a promoter for faster gas hydrate formation.

Taking into account multiple ways of promoting gas hydrate formation rate, the proposed alternative methods of natural gas transportation seem to be quite feasible and advanced. Replacement of pipelines as a means of gas transportation will beneficially rebound upon the environment and economy of a given country.

\section{ACKNOWLEDGEMENTS}

We would like to thank Chemical and Biological Engineering Faculty, Center for Hydrate Research at Colorado School of Mines (USA) headed by Dr., Prof., Carolyn A. Koh for giving an incredible opportunity to be a part of excellent group and supporting ideas as to combining coal mining with gas hydrate technologies. We are immensely grateful for the insights and comments that have greatly helped the research. 


\section{REFERENCES}

Airey, E.M. (1968). Gas Emission from Broken Coal. An Experimental and Theoretical Investigation. International Journal of Rock Mechanics and Mining Sciences, 5(6), 475-494. https://doi.org/10.1016/0148-9062(68)90036-3

Al-Jubori, A., Johnston, S., Boyer, C., Lambert, S., Bustos, O., Pashin, J., \& Wray, A. (2009). Coalbed Methane: Clean Energy for the World. Oilfield Review, 21(2), 4-13.

Altan, D., \& Zhu, J. (2014). Formation and Stability of Dry Water for Storage and Transportation of Aqueous Solutions. Research Report. Oklahoma City: Casady School.

Anklam, M.R., \& Firoozabadi, A. (2004). Driving Force and Composition for Multicomponent Gas Hydrate Nucleation from Supersaturated Aqueous Solutions. The Journal of Chemical Physics, 121(23), 11867-11875. https://doi.org/10.1063/1.1817999

Artemenko, A.I. (1980). Organic Chemistry. Moscow: Higher School.

A Regional Handbook for Coalbed Methane Degasification in the Southern Shanxi Province China. (2011). Virginia: Virginia Center for Coal and Energy Research.

Australian Government. (2006). Coalbed Methane. Research Report. Symonston: Geoscience Australia.

Bland, E. (2008). Dry Water Makes Storage a Gas. ABC Science, pp. 2-4. Retrieved from http://www.abc.net.au/science/ articles/2008/09/18/2367987.htm

Brown, T.D., Taylor, C.E., \& Bernardo, M.P. (2010). Rapid Gas Hydrate Formation Processes: Will They Work? Energies, 3(6), 1154-1175. https://doi.org/10.3390/en3061154

Brown Coal Statistics (German). (2014). Essen: Statistik der Kohlenwirtschaft.

Bue, C. (2012). Deliverability of Coalbed Methane. Trondheim: Norwegian University of Science and Technology.

Che, C.B., Yang, H.L., Li, F.B., Liu, C.L., Zhu, J., Li, Y.X., \& Tang, W.L. (2008). Exploration and Development Prospects of Coal Bed Methane (CBM) Resources in China. China Mining Magazine, 17(5), 1-4.

Coalbed Methane: The Evil Twin of Shale Gas. (2012). Retrieved from http://frack-off.org.uk/coal-bed-methanethe-evil-twin-of-shale-gas

Coal Mine Methane in Ukraine: Opportunities for Production and Investment in the Donetsk Coal Basin. (2001). Research Report. Washington, United States Environmental Protection Agency.

Coal Mine Methane in Russia. Capturing the Safety and Environmental Benefits. (2009). Paris: International Energy Agency.

Coal of Ukraine. (2013). Scientific Report. London: Baker Tilly International.

Creedy, D.P. (1991). An Introduction to Geological Aspects of Methane Occurrence and Control in British Deep Coal Mines. Quarterly Journal of Engineering Geology and Hydrogeology, 24(2), 209-220.

https://doi.org/10.1144/gsl.qjeg.1991.024.02.04

Davidson, R.M., Sloss, L.L., \& Clarke, L.B. (1995). Coalbed Methane Extraction. London: IEA Coal Research.

Developments in India-CMM/CBM. (2010). Coal Mine Methane "Project Development Status and Trends for the Methane to Markets" EXPO. Port Louis: Essar Energy, Essar Exploration \& Production Ltd.

Dinkelbach, L., \& Mader, R. (2004). Capture and Use of Methane from Operating and Abandoned mines in Germany. In International Methane \& Nitrous Oxide Mitigation Conference. Bejing: GAS Energietechnologie $\mathrm{GmbH}$.

Dudley D., Rice. (1993). Composition and Origins of Coalbed Gas. AAPG Bulletin, (77), 159-184. https://doi.org/10.1306/d9cb61eb-1715-11d7-8645000102c1865d
Fakharian, H., Ganji, H., Naderi Far, A., \& Kameli, M. (2012). Potato Starch as Methane Hydrate Promoter. Fuel, (94), 356-360. https://doi.org/10.1016/j.fuel.2011.10.029

Fandiño, O., \& Ruffine, L. (2014). Methane Hydrate Nucleation and Growth from the Bulk Phase: Further Insights into Their Mechanisms. Fuel, (117), 442-449. https://doi.org/10.1016/j.fuel.2013.10.004

Fossil Energy Research Benefits. Coalbed Methane. (2012). Washington: Office of Fossil Energy.

Fuhrhop, J.-H., \& Koning, J. (1996). Membranes and Molecular Assemblies; The Synkinetic Approach. Journal of the American Chemical Society, (117), 10790. Journal of the American Chemical Society, 118(43), 10678-10678. https://doi.org/10.1021/ja965436m

Ganushevych, K., Sai, K., \& Korotkova, A. (2014). Creation of Gas Hydrates from Mine Methane. New Developments in Mining Engineering 2015: Theoretical and Practical Solutions of Mineral Resources Mining, 505-509. https://doi.org/10.1201/b17547-85

Global Methane Initiative. (2014). International Coal Mine Methane Projects Database.

Gudmundsson, J.-S., Parlaktuna, M., \& Khokhar, A.A. (1994). Storage of Natural Gas as Frozen Hydrate. SPE Production \& Facilities, 9(01), 69-73. https://doi.org/10.2118/24924-pa

Guidebook on Coalbed Methane Drainage for Under-Ground Coal Mines. (1999). Research Report. Washington: U.S. Environmental Protection Agency.

Ham, Y.S., \& Kantzas, A. (2008). Development of Coalbed Methane in Australia: Unique Approaches and Tools. In CIPC/SPE Gas Technology Symposium 2008 Joint Conference. Alberta: Society of Petroleum Engineers. https://doi.org/10.2118/114992-ms

Hu, G., Ye, Y., Liu, C., Meng, Q., Zhang, J., \& Diao, S. (2011). Direct Measurement of Formation and Dissociation Rate and Storage Capacity of Dry Water Methane Hydrates. Fuel Processing Technology, 92(8), 1617-1622. https://doi.org/10.1016/j.fuproc.2011.04.008

India's ONGC to Start Coal-Bed Methane Production Next Year. (2015). Retrieved from http://www.miningweekly. com/article/indias-ongc-to-start-coal-bed-methane-productionnext-year-2015-10-28

Kalogerakis, N., Jamaluddin, A.K.M., Dholabhai, P.D., \& Bishnoi, P.R. (1993). Effect of Surfactants on Hydrate Formation Kinetics. In Proceedings of SPE International Symposium on Oilfield Chemistry. New Orleans: Society of Petroleum Engineers. https://doi.org/10.2523/25188-ms

Kashchiev, D., \& Firoozabadi, A. (2002). Driving Force for Crystallization of Gas Hydrates. Journal of Crystal Growth, 241(1-2), 220-230. https://doi.org/10.1016/s0022-0248(02)01134-x

Katoh, H., \& Fukazawa, K. (2011). Development of the Silo for Natural Gas Hydrate (NGH) Pellet. In International Conference on Gas Hydrates. Edinburgh: ICGH.

Kim, A.G. (1973). The Composition of Coalbed Gas. Report of Investigations 7762. Pittsburgh: Pittsburgh Mining and Safety Research Center.

Krevelen, D.W. (1961). Coal: Typology, Chemistry, Physics, Constitution. New York: Elsevier Publishing Co.

Kumar, H., \& Mathews, J.P. (2006). An Overview of Current Coalbed Methane Extraction Technologies. Houston: Research Partnership to Secure Energy for America.

Kumar, A., Bhattacharjee, G., Kulkarni, B.D., \& Kumar, R. (2015). Role of Surfactants in Promoting Gas Hydrate Formation. Industrial \& Engineering Chemistry Research, 54(49), 12217-12232. https://doi.org/10.1021/acs.iecr.5b03476 
Li, J., Liang, D., Guo, K., Wang, R., \& Fan, S. (2006). Formation and Dissociation of HFC134a Gas Hydrate in NanoCopper Suspension. Energy Conversion and Management, 47(2), 201-210. https://doi.org/10.1016/j.enconman.2005.03.018

Lv, X., Shi, B., Wang, Y., \& Gong, J. (2013). Study on Gas Hydrate Formation and Hydrate Slurry Flow in a Multiphase Transportation System. Energy \& Fuels, 27(12), 7294-7302. https://doi.org/10.1021/ef401648r

Mannel, D., \& Puckett, D. (2008). Transportation and Storage of Natural Gas Hydrates.

Martin, G., Sinquin, A., \& Darbouret, M. (2011). Hydrate Slurry Characterization for Laminar and Turbulent Flows in Pipelines. In International Conference on Gas Hydrates. Edinburgh: ICGH.

Mimachi, H., Takeya, S., Yoneyama, A., Hyodo, K., Takeda, T., Gotoh, Y., \& Murayama, T. (2014). Natural Gas Storage and Transportation Within Gas Hydrate of Smaller Particle: Size Dependence of Self-Preservation Phenomenon of Natural Gas Hydrate. Chemical Engineering Science, (118), 208-213. https://doi.org/10.1016/j.ces.2014.07.050

Miyazaki, S. (2005). Coalbed Methane Growing Rapidly as Australia Gas Supply Diversifie. Oil \& Gas Journal, 103(28), 32-36.

Mosle, B., Kukla, P., Stollhofe, H., \& Preube, A. (2009). Coal Bed Methane Production in the Munsterland Basin, Germany - Past and the Future. Geophysical Research Abstracts, (11).

Mottahedin, M., Varaminian, F., \& Mafakheri, K. (2011). Modeling of Methane and Ethane Hydrate Formation Kinetics Based on Non-Equilibrium Thermodynamics. Journal of Non-Equilibrium Thermodynamics, 36(1), 3-22. https://doi.org/10.1515/jnetdy.2011.002

Mu, F., Zhong, W., Zhao, X., Che, C., Chen, Y., Zhu, J., \& Wang, B. (2015). Strategies for The Development of CBM Gas Industry in China. Natural Gas Industry B, 2(4), 383-389. https://doi.org/10.1016/j.ngib.2015.09.013

Ohmura, R., Kashiwazaki, S., Shiota, S., Tsuji, H., \& Mori, Y.H. (2002). Structure-I and Structure-H Hydrate Formation Using Water Spraying. Energy \& Fuels, 16(5), 1141-1147.

https://doi.org/10.1021/ef0200727

Ojha, K., Karmakar, B., Mandal, A., \& Pathak, A.K. (2011). Coal Bed Methane in India: Difficulties and Prospects. International Journal of Chemical Engineering and Applications, 2(4), 256-260. https://doi.org/10.7763/ijcea.2011.v2.113

ONGC to Invest Rs 3500 Crore for Developing Three CBM Blocks. (2015). Retrieved from http://economictimes. indiatimes.com/articleshow $/ 50300665 . \mathrm{cms}$ ? intenttarget=no \&utm_source $=$ contentofinterest\&utm_medium=text\&utm campaign $=\mathrm{cppst}$

O perspektivakh dobychi $v$ Rossii ugol'nogo gaza. (2017). Retrieved from http://www.gazprom.ru/about/production/ extraction/metan/

Prasad, P.S.R., Sowjanya, Y., \& Dhanunjana Chari, V. (2014). Enhancement in Methane Storage Capacity in Gas Hydrates Formed in Hollow Silica. The Journal of Physical Chemistry $C, 118(15), 7759-7764$. https://doi.org/10.1021/jp411873m

Puchcov, L.A., Slastunov, S.V., \& Karkashadze, G.G. (2006). Methane Recovery and Utilization from Coal Seams in Russia. Global Methane Initiative, 5-25.

Raspadskaya Mine Explosion. (2010). Retrieved from https://en.wikipedia.org/wiki/Raspadskaya mine explosion

Real Potential: India's Coal Bed Methane Development. (2015). Retrieved from http://www.theoilandgasyear.com/interviews /real-potential-indias-coal-bed-methane-development/
Rehder, G., Eckl, R., Elfgen, M., Falenty, A., Hamann, R., Kähler, N., \& Windmeier, C. (2012). Methane Hydrate Pellet Transport Using the Self-Preservation Effect: A TechnoEconomic Analysis. Energies, 5(12), 2499-2523. https://doi.org/10.3390/en5072499

Ruban, A.D. (2006). Methane in the Mines of Russia: Forecasting, Extraction and Usage. Moscow: IPKON RAN.

Said, S., Govindaraj, V., Herri, J.-M., Ouabbas, Y., Khodja, M., Belloum, M., \& Nagarajan, R. (2016). A Study on the Influence of Nanofluids on Gas Hydrate Formation Kinetics and Their Potential: Application to the $\mathrm{CO}_{2}$ Capture Process. Journal of Natural Gas Science and Engineering, (32), 95-108. https://doi.org/10.1016/j.jngse.2016.04.003

Servio, P., \& Englezos, P. (2002). Measurement of Dissolved Methane in Water in Equilibrium with Its Hydrate. Journal of Chemical \& Engineering Data, 47(1), 87-90. https://doi.org/10.1021/je0102255

Shindell, D.T., Faluvegi, G., Koch, D.M., Schmidt, G.A., Unger, N., \& Bauer, S.E. (2009). Improved Attribution of Climate Forcing to Emissions. Science, 326(5953), 716-718. https://doi.org/10.1126/science.1174760

Shirato, K., \& Satoh, M. (2011). "Dry Ionic Liquid" as a NewComer to "Dry Matter". Soft Matter, 7(16), 7191. https://doi.org/10.1039/c1sm05999h

Song, K., Feneyrou, G., Fleyfel, F., Martin, R., Lievois, J., \& Kobayashi, R. (1997). Solubility Measurements of Methane and Ethane in Water at and Near Hydrate Conditions. Fluid Phase Equilibria, 128(1-2), 249-259. https://doi.org/10.1016/s0378-3812(96)03165-2

Statistical Review of World Energy. (2008). Research Report. London: BP.

Stearns, M., Tindall, J.A., Cronin, G., Friedel, M.J., \& Bergquist, E. (2005). Effect of Coal-Bed Methane Discharge Waters on Vegetation and Soil Ecosystems in Powder River Basin. Water, Air, \& Soil Pollution, 168 (1-4), 33-57. https://doi.org/10.1007/s11270-005-0588-Z

Taheri, Z., Shabani, M.R., Nazari, K., \& Mehdizaheh, A. (2014). Natural Gas Transportation and Storage by Hydrate Technology: Iran Case Study. Journal of Natural Gas Science and Engineering, (21), 846-849. https://doi.org/10.1016/j.jngse.2014.09.026

Thakur, P. (2017). Global Reserves of Coal Bed Methane and Prominent Coal Basins. Advanced Reservoir and Production Engineering for Coal Bed Methane, 1-15. https://doi.org/10.1016/b978-0-12-803095-0.00001-6

The Unconventional Hydrocarbon Resources of Britain's Onshore Basins - Coalbed Methane. (2013). Information Report. London: Department of Energy and Climate Change.

Tien, J.C. (1996). U.S. Mine Ventilation Regulations. Rotterdam: Balkema.

Ukraine Coalbed Methane Project (GEF). (1998). Technical Review. Global Environment Facility.

Ukraine's Mine Death Toll Rises. (2007). Retrieved from http://news.bbc.co.uk/2/mobile/europe/7103086.stm

Wang, W., Bray, C.L., Adams, D.J., \& Cooper, A.I. (2008). Methane Storage in Dry Water Gas Hydrates. Journal of the American Chemical Society, 130(35), 11608-11609. https://doi.org/10.1021/ja8048173

Wu, J., Sun, M., \& Feng, S. (2011). Good Lessons from The State-Level Demonstration Project of Coalbed Methane Development: An Overview of Such High-Tech and Commercial Project in The Southern Qinshui Basin. Natural Gas Industry, 31(5), 9-15.

Welander, P., \& Vincent, T.L. (1999). Designing and Optimizing Gas/Liquid Reactions for: Environmental Processes/Chemical Reactions/Heat Transfer. New York: Chem Show.

Zhong, Y., \& Rogers, R.E. (2000). Surfactant Effects on Gas Hydrate Formation. Chemical Engineering Science, 55(19), 4175-4187.

https://doi.org/10.1016/s0009-2509(00)00072-5 


\section{ABSTRACT (IN UKRAINIAN)}

Мета. Дослідження основних фізичних і хімічних властивостей вугільного метану, умов його формування та місць виникнення. Особлива увага приділяється утилізації метану із використанням альтернативних методів, таких як газогідратні технології та нанотехнології.

Методика. Аналіз геологічних умов утворення вугільного метану та його речовинного складу в декількох країнах, а також вивчення методів збільшення швидкості гідратоутворення для інтенсифікації утилізації газу.

Результати. Класифіковані запаси вугільного метану у відповідності з його кількістю в різних країнах світу. Проведено широкий огляд методів інтенсифікації гідратоутворення й застосування нанотехнологій, використовуючи різні хімічні речовини для утилізації та транспортування вугільного метану у твердій формі.

Наукова новизна. Газові гідрати і суха вода були запропоновані в якості альтернативних методів утилізації вугільного метану та його транспортування у твердій формі.

Практична значимість. Колосальна кількість метану, що виділяється в атмосферу з підземних вугільних шахт, може бути переведена у тверду або порошкову форму для транспортування на значні відстані при помірних термобаричних умовах.

Ключові слова: вугільний метан, парникові гази, газові гідрати, суха вода, наночастки, транспортування газу, використання поверхнево-активних речовин, розпилення води

\section{ABSTRACT (IN RUSSIAN)}

Цель. Исследование основных физических и химических свойств угольного метана, условий его формирования и мест возникновения. Особое внимание уделяется утилизации метана с использованием альтернативных методов, такие как газогидратные технологии и нанотехнологии.

Методика. Анализ геологических условий образования угольного метана и его вещественного состава в нескольких странах, а также изучение методов увеличения скорости гидратообразования для интенсификации утилизации газа.

Результаты. Классифицированы запасы угольного метана в соответствии с его количеством в различных странах мира. Проведен широкий обзор методов интенсификации гидратообразования и применения нанотехнологий, используя различные химические вещества для утилизации и транспортирования угольного метана в твердой форме.

Научная новизна. Газовые гидраты и сухая вода были предложены в качестве альтернативных методов утилизации угольного метана и его транспортирования в твердой форме.

Практическая значимость. Колоссальное количество метана, выделяемое в атмосферу из подземных угольных шахт, может быть переведено в твердую или порошковую форму для транспортировки на большие расстояния при умеренных термобарических условиях.

Ключевые слова: угольный метан, парниковые газы, газовые гидраты, сухая вода, наночастицы, транспортировка газа, использование поверхностно-активных веществ, распыление воды

\section{ARTICLE INFO}

Received: 24 May 2017

Accepted: 7 September 2017

Available online: 30 September 2017

\section{ABOUT AUTHORS}

Kostiantyn Hanushevych, Doctor of Philosophy, Research Stuff of the Department of Chemical and Biological Engineering, Colorado School of Mines, 1500 Illinois St, Alderson Hall, CO 80401, Golden, United States, E-mail: kosganush@gmail.com

Vishal Srivastava, PhD Student of the Department of Chemical and Biological Engineering, Colorado School of Mines, 1500 Illinois St, Alderson Hall, CO 80401, Golden, United States, E-mail: vsrivast@mymail.mines.edu 